\title{
Immunoglobulin-Binding Protein 1
}

National Cancer Institute

\section{Source}

National Cancer Institute. Immunoglobulin-Binding Protein 1. NCI Thesaurus. Code C26637.

Immunoglobulin-binding protein 1 (339 aa, $39 \mathrm{kDa}$ ) is encoded by the human IGBP1 gene. This protein plays a role in the modulation of both protein phosphatase activity and B-cell receptor-mediated signaling. 